UDK 634.232:311.16(497.6 Sarajevo)

\title{
NEKI KORELACIJSKI ODNOSI IZMEĐU SVOJSTAVA PUPOVA, CVIJETA I SJEMENA DIVLJE TREŠNJE (Prunus avium L.) IZ POPULACIJE MRKOVIĆI
}

\section{Some correlation properties of buds, flowers and seeds of wild cherry (Prunus avium L.) in the Mrkovići population}

\author{
Ballian Dalibor i Azra Čabaravdićl
}

\begin{abstract}
:
Some properties of buds, flowers and seeds of wild cherry are analyzed using the statistical analysis in order to determine the existing relationships.

This is an attempt to relate the length and the width of the flower buds with (1) the length and the width of the flowers and blossoms and (2) the length, width and thickness of the seeds. The obtained results could be used for estimation of the richness of blossoming, the seed sizes and consequently the fruit sizes that could have great significance in establishment of artificial stands of wild cherry selection related to fruit productivity
\end{abstract}

Key words: cherry (Prunus avium L.), population, variability, corelation.

\section{Izvod}

Statističkom korelacijskom analizom nekih svojstava pupova, cvijeta i sjemena divlje trešnje pokušali smo utvrditi stupanj njihove povezanosti.

Ovim istraživanjem smo željeli utvrditi zavisnost između duljine i debljine cvjetnih pupova, sa jedne strane, dužine i širine cvijeta i broja cvjetova u gronji, s druge strane, te dužine, širine i debljine sjemena na trećoj strani. Dobiveni rezultati nam omogućavaju da napravimo procjenu obilnosti cvjetanja, te procjenu veličine sjemena a na temelju toga i ploda, što može igrati veliku ulogu kod podizanja sjemenskih plantaža ili kod selekcije divljih trešanja po svojstvu proizvodnosti ploda.

Ključne riječi: trešnja (Prunus avum L.), populacija, varijabilnost, korelacija

\footnotetext{
${ }^{1}$ Šumarski fakultet Univerziteta u Sarajevu - Faculty of Forestry University of Sarajevo
} 


\section{UVOD - Introduction}

Divlja trešnja (Prunus avium L.) je još 1954. god. proglašena "Drvom budućnosti" (BEJDL, 1954), ali se ipak do unazad dvije decenije nije puno vodilo računa o njoj. Dolazi u brzorastuće vrste, sa ophodnjom od 40 od 60 godina kada završava svoje prirašćivanje (JOVANOVIĆ 2000). S gospodarskog i ekološkog motrišta divlja trešnja je jedna od najznačajnijih vrsta šumskog drveća u Bosni i Hercegovini i u više europskih zemalja. Međutim, ne pridaje joj se velika pažnja kakvu zaslužuje. Zakonom o šumama bila je zabranjena sječa šumskih voćkarica, pa i divlje trešnje, ali u poslijeratnom periodu od 1996. do 2000. godine u BiH je praktično posječena sva divlja trešnja koja je mogla poslužiti za preradu. Tako je nesavjesnim i nestručnim poslovanjem šumarskih stručnjaka za sitne novce, ozbiljno narušena genetička struktura.

Mnogostruk je i veoma velik značaj divlje trešnje jer se njeni plodovi koriste za ishranu ljudi i životinja. Među velikim brojem vrsta koje imaju koštičave plodove, ističe se ipak kao najznačajnija sa velikom privrednom vrijednošću. Kao podloga za kalemljenje koriste se sijanci proizvedenih od formi divlje trešnje, glatke kore, sitnih, crnih i gorkih plodova koji kasno sazrijevaju. Zbog ranog i obilnog cvjetanja predstavljaju odličnu pašu za pčele. Čaj od trešnjinih peteljki odličan je diuretik i regulator krvnog pritiska. Trešnje crnih plodova sadrže antocijane koji imaju dijetoprofilaktičko i terapeutsko djelovanje na vid (HERMAN 1971). Drvo divlje trešnje je cijenjeno u preradi drveta jer služi pri izradi namještaja kao imitacija mahagonija, te na svjetskom tržištu postiže veliku cijenu. Pogodna je za podizanje drvoreda i poljozaštitnih pojaseva jer je dekorativna, medonosna, ljekovita, plodovi su joj jestivi, a daje uz to i vrijednu drvnu masu.

Sa ekološkog gledišta vrlo je značajna zbog svoje ekološke prilagodljivosti. Javlja se od nizinskih šuma uz riječne tokove do područja visoko planinske bukve, na granici šumske vegetacije. Međutim, najčešće se javlja na rubovima šuma i na mjestima gdje se zadržavaju ptice koje su glavni prenosioci sjemena.

Prva istraživanja varijabilnosti divlje trešnje u $\mathrm{BiH}$ započeta su 1990. godine (MIKIĆ, 1990). Sakupljen je obiman materijal i odgajano half-sib potomstvo od preko 200 familija. Radovi su prekinuti uslijed ratnih događanja u $\mathrm{BiH}$, a podaci i odgojeno potomstvo su uništeni. U poslijeratnom periodu nedostatak sredstava onemogućio je veće radove sa divljom trešnjom, ali se pristupilo lokalnim istraživanjima morfoloških i genetičkih parametara. (BALLIAN 2000, 2002, 2004; MIKIĆ i sur., 2004)

Literaturni podaci o morfološkoj varijabilnosti divlje trešnje su vrlo oskudni, iako KLEINSCHMIT i sur. (2000) ukazuje na njenu veliku varijabilnost. Mogu se naći samo opći podaci za određena svojstva, prije svega o sjemenu, nešto malo o cvijetu (Ballian, 2002; Clemants, 1996; HiekE, 1989; Jovanović, 1972; KRÜSSMAnN, 1978; RUSHFORTH, 1999), i o veličini ploda koja služe za taksonomiju divlje trešnje. Tako se za divlju trešnju sitnih plodova, koji su u zrelom stanju crne boje kaže da je to varijetet Prunus aviun var. actiana L. (HERMAN, 1971) ili čista divlja trešnja. 


\section{Cilj istraživanja}

Statističkom korelacijskom analizom svojstava pupoljaka, cvijeta i sjemena pokušat će se utvrditi stupanj njihove povezanosti.

Ovim istraživanjem smo željeli utvrditi zavisnost između duljine i debljine cvjetnih pupova, sa jedne strane, dužine i širine cvijeta i broja cvjetova u gronji, s druge strane, te dužine, širine i debljine sjemena na trećoj strani. Dobiveni rezultati nam omogućavaju da napravimo procjenu obilnosti cvjetanja, te procjenu veličine sjemena a na temelju toga i ploda, što može igrati veliku ulogu kod podizanja sjemenskih plantaža ili kod selekcije divljih trešanja po svojstvu proizvodnosti ploda.

Dobiveni rezultati bi omogućili i bolje razumijevanje i bolji pregled fenotipske i genetičke varijabilnosti lokalnih populacija. To je vrlo bitna pretpostavka i osnova za planiranje i izdvajanje sjemenskih objekata divlje trešnje i njenu rajonizaciju, zatim zbog radova na očuvanju genofonda divlje trešnje, te njenoj konzervaciji in situ i ex situ.

\section{MATERIJAL I METODE RADA - Material and Methods}

\section{Uvjeti staništa}

Klima - Za prikazivanje klimatskih uvjeta koriste se podaci meteorološke stanice Sarajevo (Bjelave), na $630 \mathrm{~m} / \mathrm{nm}$, koja se nalazi oko 1-2 km od istraživanog objekta, koji se nalazi na oko $950-1050 \mathrm{~m} / \mathrm{nm}$.

Prosječna godišnja temperatura je $9,7^{\circ} \mathrm{C}$, a srednja temperatura u razdoblju IV - IX mjesec iznosi $15,5^{\circ} \mathrm{C}$.

Prosječna godišnja količina padavina iznosi $946 \mathrm{~mm}$, a za period od IV-IX mjesec je $450 \mathrm{~mm}$.

Srednja relativna vlažnost zraka je $72 \%$, a za period od IV do IX mjeseca $67 \%$.

Vrijednost De Martonneovog indeksa suše za period od IV do IX mjeseca je 17,6. Indeks klime Im je 1 što odgovara prelazno aridnom tipu klime.

Temperature, padavine i njihov raspored ukazuju na izmijenjeno kontinentalni karakter klime.

Tlo - Matični supstrat je vapnenac i verfen, na kome se razvilo smeđe vapnenasto zemljište, a na verfenu crvenice. Na manjim površinama je prisutan sirovi humusom koji se nalazi na samom matičnom supstratu. Tlo je propusno za vodu, ali postoji dosta izvora i površinskih tokova u jarugama.

Vegetaciju na ovom području predstavljaju degradirane šume, sa jakim antropogenim i zoogenim utjecajem, najčešći šibljaci, sa dosta crnog jasena, graba, drena, jasike i ljeska. Divlja trešnja obično dolazi kao rubna vrsta uz livade ili u međama.

Trenutno stanje - Degradirane šume, koje se nalaze u društvenom vlasništvu direktno se prevode u visoke šume pošumljavanjem crnim i običnim borom. 


\section{Sabiranje materijala za analizu}

Materijal divlje trešnje sabran je tijekom zimskog mirovanja, proljetnog i ljetnog perioda u populaciji Mrkovići, tri kilometra sjeveroistočno od Sarajeva, tijekom 1999. godine. Prilikom sabiranja zimskih pupova stabla su obilježena brojevima od 1 do 30 masnom bojom da bi se olakšao rad u proljeće kad su mjereni cvjetovi, te ljeto kad je sabrano sjeme.

Populaciju karakterizira prisustvo velikog broja hibridnih individua, divlje i domaće trešnje (BALLIAN, 2000), što daje jedan specifikum istraživanoj populaciji, ali može otežati i interpretaciju dobivenih rezultata.

Pupovi, cvjetovi i sjeme za morfološku analizu sabrani su sa 30 selekcioniranih stabala ravnomjerno raspoređenih na području istraživane populacije. Sa svakog od stabala u zimskom periodu je iz južno eksponiranog dijela, vanjske strane krošnje sakupljeno po 30 cvjetnih pupoljaka, sa kratkih fertilnih izbojaka, za morfometrijska mjerenja. Grane sa kojih su sabrani uzorci su obilježene žutim prstenom. Tijekom cvjetanja divlje trešnje, krajem travnja i početkom svibnja, sa obilježenih grana su sabrani cvjetovi sa kratkih fertilnih izbojaka. Nakon obrazovanja plodova, te njihovog sazrijevanja, sa istih grana po istoj metodi sabrano je po 30 plodova iz kojih su izdvojene sjemenke za daljnju analizu. Tako je sabrano ukupno 900 pupoljaka, cvjetnih gronja i plodova (sjemena).

Svi sabrani pupoljci, cvijetovi i sjeme su mjereni pomičnim elektronskim mjerilom i točnošću od 100-og dijela milimetra.

\section{Mjerena svojstva i analiza}

$\mathrm{Na}$ svakom pupoljku su mjereni Dp-dužina i Šp-širina pupa. Na svakom cvijetu su mjereni Šc-širina cvijeta i Bc-broj cvjetova u gronji. Na svakom sjemenu su mjereni Ds-dužina, Šs-širina i De-debljina sjemena. Također su obrađeni i slijedeći odnosi: Dp-dužine i Šp-širine pupoljka, Šs-širine i De-debljine sjemena, Ds-dužine i De-debljine sjemena, te Ds-dužine i Šs-širine sjemena. Svi izmjereni uzorci su uneseni su u osobno računalo, izvedeni su osnovni statistički pokazatelji i provedene analize varijanse (ANOVA), korelacijska i regresijska analiza pomoću programa Excel.

\section{REZULTATI ISTRAŽIVANJA - Results}

\section{Statistička analiza - Statistical analysis}

Rezultati dobiveni ovom analizom prikazani su u tablici 1. Oni predstavljaju osnovne deskriptivne pokazatelje (raspon, varijacije, minimum, maksimum, prosjek i standardna devijacija). Tako su dobivene veličine u rasponu podataka koje navodi BALlian (2000, 2002) za sjeme i cvijet, Jovanović (1972) za cvijet, te CemanTS (1996), HIEKE (1989), KRÜSSMANN (1978) I RUSHFORTH (1999). 
Za broj cvjetova u gronji, HIEKE (1989) navodi 4-6, JovANović (1972) i KRAMER (1984) 2-6, a 2-5 RIEGER (2002), dok BALLIAN (2002) navodi 2-6, s tim da je najviše individua koje imaju od 3 do 5 cvjetova u gronji.

ANOVA je pokazala da postoji statistički značajna razlika prosječnih veličina cvjetova kod različitog broja cjetova u gronji $(\mathrm{F}=9,68, \mathrm{p}=0,000)$. U slučaju dva ili pet cvjetova $u$ gronji cvjetovi su sitniji, dok se kod gronja s tri i četiri cvijeta javljaju krupniji cvjetovi.

Provedenom korelacijskom analizom između istraživanih svojstva dobili smo da u istraživanoj populaciji imamo 41 slučaju imamo statistički značajnu korelacijsku vezu na razini od 0,01 , za istraživana svojstva. U 4 slučaja smo utvrdili postojanje statistički značajne korelacije između istraživanih svojstava na razini 0,05 , a u 10 slučajeva za istraživana svojstva nije registrirana njihova korelacijska povezanost (Tabela 2). Tako sva istraživana svojstva koja pokazuju statistički značajnu korelaciju mogu poslužiti u aktivnostima na procjeni obilnosti cvjetanja, te veličine i oblika sjemena, a s time i ploda.

Analizom linearne proste i višestruke regresije ustanovljene su statističke regresijske značajnosti između: dužine i širine pupa $(R=0,43)$, širine cvijeta $i$ širine pupa $(\mathrm{R}=0,18)$, širine i dužine sjemena $(\mathrm{R}=0,45)$, debljine sjemena u odnosu na dužinu $\mathrm{i}$ širinu sjemena $(R=0,92)$, te dužine pupa u odnosu na omjer dužine $i$ širine sjemena $(\mathrm{R}=0,31)$. Regresijski pokazatelji prostih i višestrukih međuzavisnosti dati su u tablici 3 .

Tabela 1. Deskriptivni statistički pokazatelji

Table 1. Descriptive statistics

\begin{tabular}{|c|c|c|c|c|c|c|c|}
\hline & $\begin{array}{l}\sum_{2}^{2} \\
\frac{n}{2} \\
\dot{3} \\
n\end{array}$ & 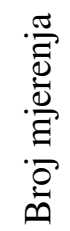 & 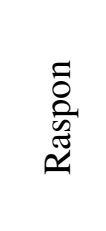 & $\stackrel{\Xi}{\Xi}$ & 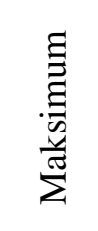 & 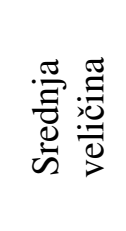 & 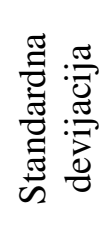 \\
\hline \multirow{2}{*}{$\cong$} & Dp-dužina & 900 & 5,18 & 2,81 & 7,99 & 6,033 & 0,650 \\
\hline & Šp-širina & 900 & 3,85 & 2,23 & 6,08 & 3,375 & 0,449 \\
\hline \multirow{2}{*}{ : } & Šc-širina & 900 & 17,31 & 20,35 & 37,66 & 27,733 & 3,015 \\
\hline & Bc-broj u gronji & 900 & 4,00 & 2,00 & 6,00 & 3,286 & 0,648 \\
\hline \multirow{3}{*}{$\underset{\mathscr{E}}{\stackrel{\mathscr{E}}{\Omega}}$} & Ds-dužina & 900 & 4,58 & 6,72 & 11,30 & 8,630 & 0,863 \\
\hline & Šs-širina & 900 & 3,42 & 5,55 & 8,97 & 7,147 & 0,554 \\
\hline & De-debljina & 900 & 2,97 & 4,28 & 7,25 & 5,667 & 0,455 \\
\hline \multirow{4}{*}{$\begin{array}{l}\overline{\tilde{O}} \\
\overline{0} \\
\overline{0}\end{array}$} & Dp i Šp pupoljka & 900 & 1,62 & 0,92 & 2,54 & 1,807 & 0,231 \\
\hline & Ss i De sjemena & 900 & 0,47 & 0,92 & 1,39 & 1,262 & 0,044 \\
\hline & Ds i De sjemena & 900 & 0,91 & 1,15 & 2,06 & 1,529 & 0,170 \\
\hline & Ds i Šs sjemena & 900 & 0,61 & 0,94 & 1,55 & 1,210 & 0,112 \\
\hline
\end{tabular}


Neki korelacijski odnosi između svojstava pupova, cvijeta i sjemena divlje trešnje

(Prunus avium L.) iz populacije Mrkovići

Tabela 2. Korelacijski odnosi istraživanih svojstava

Table 2. Correlations between the examined variables

\begin{tabular}{|c|c|c|c|c|c|c|c|c|c|c|c|c|c|}
\hline \multirow{2}{*}{1} & \multirow{2}{*}{\multicolumn{2}{|c|}{ Korelacija }} & \multicolumn{2}{|c|}{ Pup } & \multicolumn{2}{|c|}{ Cvijet } & \multicolumn{3}{|c|}{ Sjeme } & \multicolumn{4}{|c|}{ Odnosi } \\
\hline & & & \multirow{2}{*}{$\begin{array}{c}\text { Dp- } \\
\text { dužina }\end{array}$} & \multirow{2}{*}{$\begin{array}{c}\begin{array}{c}\text { Šp- } \\
\text { Širina }\end{array} \\
\end{array}$} & \multirow{2}{*}{$\begin{array}{c}\text { Šc- } \\
\text { Širina }\end{array}$} & \multirow{2}{*}{$\begin{array}{l}\text { Bc-broj } \\
\text { u gronji }\end{array}$} & \multirow{2}{*}{$\begin{array}{c}\text { Ds- } \\
\text { dužina }\end{array}$} & \multirow{2}{*}{$\begin{array}{c}\text { Šs- } \\
\text { Širina }\end{array}$} & \multirow{2}{*}{$\begin{array}{c}\text { De- } \\
\text { debljina }\end{array}$} & \multirow{2}{*}{$\begin{array}{c}\text { Dp i Šp } \\
\text { pupoljka }\end{array}$} & \multirow{2}{*}{$\begin{array}{c}\begin{array}{c}\text { Šs i De } \\
\text { sjemena }\end{array} \\
\end{array}$} & \multirow{2}{*}{$\begin{array}{c}\text { Ds i De } \\
\text { sjemena }\end{array}$} & \multirow{2}{*}{$\begin{array}{c}\text { Ds i } \check{S ̆ s} \\
\text { sjemena }\end{array}$} \\
\hline \multirow{3}{*}{$\hat{z}$} & $\begin{array}{c}\text { Dp- } \\
\text { dužina }\end{array}$ & Korelacija & & & & & & & & & & & \\
\hline & \multirow{2}{*}{ Šp-širina } & Korelacija & 0,419 ** & & & & & & & & & & \\
\hline & & Značajnost & 0,000 & - & & & & & & & & & \\
\hline \multirow{2}{*}{ : } & Šc-širina & Korelacija & $0,113^{* *}$ & 0,172 ** & & & & & & & & & \\
\hline & $\begin{array}{c}\text { Bc-broj u } \\
\text { gronji }\end{array}$ & Značajnost & $0,733^{* *}$ & 0,017 & 0,038 & - & & & & & & & \\
\hline \multirow{5}{*}{ 节 } & \multirow{2}{*}{ Ds-dužina } & Korelacija & $0,116^{* *}$ & 0,006 & $0,076^{*}$ & $-0.199 * *$ & & & & & & & \\
\hline & & Značajnost & 0,000 & 0,857 & 0,023 & 0,000 & - & & & & & & \\
\hline & \multirow{2}{*}{ Šs-širina } & Korelacija & $-0,233^{* *}$ & $0,094 * *$ & $-0,007$ & $-0,114^{* *}$ & $0,453^{* *}$ & & & & & & \\
\hline & & Značajnost & 0,000 & 0,005 & 0,823 & 0,001 & 0,000 & - & & & & & \\
\hline & $\begin{array}{c}\text { De- } \\
\text { debljina }\end{array}$ & Korelacija & $-0,262 * *$ & 0,046 & 0,005 & $-0,091 * *$ & $0,254 * *$ & $0,902^{* * *}$ & & & & & \\
\hline \multirow{6}{*}{$\stackrel{\overrightarrow{\mathscr{g}}}{\stackrel{\Xi}{0}}$} & \multirow{2}{*}{$\begin{array}{c}\text { Šs i De } \\
\text { sjemena }\end{array}$} & Korelacija & $0,088^{* *}$ & $0,121 * *$ & $-0,017$ & $-0,033$ & $0,419^{* *}$ & 0,129 ** & $-0,310 * *$ & $-0,32$ & & & \\
\hline & & Značajnost & 0,008 & 0,000 & 0,620 & 0,325 & 0,000 & 0,000 & 0,000 & 0,340 & - & & \\
\hline & Ds i De & Korelacija & $0,290 * *$ & $-0,008$ & $0,086 * *$ & $-0,105$ & $0,714 * *$ & $-0,240$ & $-0,492 * *$ & $0,262 * *$ & $0,610 * *$ & & \\
\hline & sjemena & Značajnost & 0,000 & 0,799 & 0,010 & 0,002 & 0,000 & 0,000 & 0,000 & 0,000 & 0,000 & - & \\
\hline & Ds i Šs & Korelacija & $0,310 * *$ & $-0,056$ & $0,100 * *$ & $-0,116$ & $0,686 * *$ & $-0,335$ & $-0,468$ & $0,325 * *$ & $0,344 * *$ & $0,953 * *$ & \\
\hline & sjemena & Značajnost & 0,000 & 0,091 & 0,003 & 0,001 & 0,000 & 0,000 & 0,000 & 0,000 & 0,000 & 0,000 & - \\
\hline
\end{tabular}

** značajnost korelacije na razini od $0,01, *$ značajnost korelacije na razini 0,05 
Tabela 3. Regresijski pokazatelji

Table 3. Regression parameters

\begin{tabular}{|c|c|c|c|c|}
\hline \multirow{2}{*}{ Regresijski odnosi } & \multicolumn{3}{|c|}{ Regresijski parametri } & \multirow{2}{*}{$\begin{array}{c}\text { Korelacija } \\
\mathbf{R}\end{array}$} \\
\hline & $\mathbf{a}$ & b & c & \\
\hline $\mathbf{D p}=\mathbf{f}(\stackrel{\mathbf{S} p}{\mathbf{n}})$ & 3,92 & 0,63 & & 0,43 \\
\hline $\mathbf{S c}=\mathbf{f}(\mathbf{S p})$ & 22,5 & 0,98 & & 0,18 \\
\hline De $=f(D s, \stackrel{\text { Ss}}{ })$ & 0,73 & $-0,10$ & 0,81 & 0,92 \\
\hline Ds=f(Dp) & 7,74 & 0,15 & & 0,11 \\
\hline$\check{S} \mathbf{s}=\mathbf{f}(\mathbf{D p}, \check{S} \mathbf{p})$ & 7,89 & $-0,30$ & 0,30 & 0,32 \\
\hline $\mathrm{Dp}=\mathbf{f}(\mathrm{Ds}, \stackrel{\mathrm{S} s}{ })$ & 6,48 & $-0,25$ & 0,20 & 0,32 \\
\hline
\end{tabular}

\section{RASPRAVA - Discussion}

Ekološka valencija vrste nasljedna je karakteristika, odnosno njezina je sposobnost prilagodbe određena nasljednom osnovom ili genomom biljke, što definiramo njenom fenotipskom plastičnošću. Jedno od specifičnih svojstava koje određuje tu plastičnost je učestalost cvjetanja, te oblik i veličina ploda. U radovima na oplemenjivanju veoma je bitno uspješno procijeniti obimnost cvjetanja. Kako do sada nismo imali valjane pokazatelje, ovim istraživanjem je načinjen jedan od prvih koraka u tom smjeru, a posebice saznanje da divlja trešnja predstavlja jednu veliku nepoznanicu.

U dosad obavljenim radovima o morfologiji divlje trešnje samo je na jedno mjestu rješavan problem linearne korelacije kod nekih svojstava sjemena divlje trešnje (BALLIAN, 2000, 2002). Tako da ovo istraživanje predstavlja pionirsku aktivnost, koja bi se mogla primijeniti i na druge vrste šumskog drveća.

Ovdje ćemo se posebno osvrnuti na problematiku inkompatibilnosti multiplih alela kod trešnje, jer mogu predstavljati veliku smetnju kod rješavanja ovog problema prilikom podizanja sjemenskih plantaža i arhiva. Tako serija multiplih alelomorfnih gena regulira inkompatibilnosti kod oplodnje, gdje imamo da aleli djeluju neovisno jedan od drugog o čemu izvještavaju CRANE i LAWRENCE (1956), PANDEY (1967), ASCHER (1966, 1976), PEJKIĆ (1980), MIŠIĆ (1987) i RUSSEL (2003). Broj otkrivenih alela koji reguliraju inkompatibilnost kreće se od 6 do 12 u ovisnosti od primijenjene metode istraživanja. Na ovaj način se reducira i strogo usmjerava kretanje gena $\mathrm{s}$ peludi koja će oploditi makrogametu. Sjedinjene genetičke strukture će dati potpuno drugačije odnose na potomstvu, što može otežati procjenu.

Kada se ne mogu isključiti metodički efekti (broj jedinki u uzorku) ili izbor analiziranih svojstava, razvojni i antropogeni čimbenici, što je jako izraženo kod divlje trešnje, dobivene korelacije s jakom regresijom, mogu da upućuju na to da postoje različiti adaptacijski procesi u istraživanim populacijama. U tom slučaju mogu igrati značajnu ulogu, te stoga razvoj populacije usmjeravati u određenom pravcu. Zato nam dobiveni rezultati na ovaj način mogu osigurati bolje razumijevanje i bolji pregled 
fenotipske, a time indirektno i genetičke varijabilnosti lokalnih populacija. To je veoma važna pretpostavka koja predstavlja temelj za planiranje i izdvajanje sjemenskih objekata divlje trešnje, njenu rajonizaciju. Posebna vrijednost se ogleda i u tome što omogućava lakše aktivnosti na očuvanju genofonda divlje trešnje, te njenoj konzervaciji in situ i ex situ, na temelju znanstvenih postavki.

\section{ZAKLJUČCI - Conclusion}

Sva analizirana svojstva u ovom istraživanju pokazuju veliku individualnu unutar populacijska varijabilnost, što je svojstveno svim vrstama šumskog drveća iz područja centralnih Dinarida.

Od korelacijskih veza najveću međuzavisnost pokazuje odnos debljine i širine sjemena, dok kod ostalih korelacijskih veza mnogi neobuhvaćeni čimbenici imaju velikog udjela u toj vezi.

U populacijama divlje trešnje veliko je učešće stabala koja su nastala spontanom hibridizacijom sa sortama pitome trešnje. Tako u populacijama imamo stabla $F_{1}, F_{2}, F_{3} i$ drugih generacija, što daje veliku varijabilnost populaciji za istraživana svojstva, a za neka svojstva otežava procjenu.

Dobivene veličine mogu poslužiti kao temelj za jednu sveobuhvatnu procjenu varijabilnosti. Analizirana svojstva ukazuju na mogućnost njenog korištenja pri izvođenju šumsko-uzgojnih radova, kao i za osnivanje sjemenskih baza.

Dobivene korelacije mogu poslužiti za procjenu cvjetanja i veličine sjemena, na temelju poznate veličine pupova u narednom vegetacijskom periodu.

Primijenjena metoda daje dobru sliku morfološke strukture populacije, na temelju koje se mogu preporučiti potrebne mjere za održavanje genetičkih resursa u istraživanim populacijama, za razliku od rezultata koji se dobiju standardnim analizama varijanse.

\section{LITERATURA - Literature}

1. AsCHER, P. 1966: Gene action model to explain gametophytic selfincompatibility. Euphytica, 15, 179-183.

2. AsCHER, P. 1976: Self-incompatibility systems in floriculture crops. Acta Horticultura, 63, 205-215.

3. BALLIAN, D. (2000): Početna istraživanja varijabilnosti morfoloških svojstava sjemena divlje trešnje (Prunus avium L.), Šumarski list br. 5-6: 271-278.

4. BALLIAN, D. 2002: Variability of characteristies of the wild cherry blossom (Prunus avium L.) in the region of central Bosnia. Analiza šumarstvo. Zagreb, 25/2, str. 19.

5. BALLIAN, D. (2004): Varijabilnost mikrosatelitne DNK u populacijama divlje trešnje iz središnje Bosne. Šumarski list br. 11-12: 649 - 654. 
6. BEJDL, R. 1954: Prunus avium, the tree of the future (Tresen cilova drevina blizke buducnosti). Lesen, Prace 33 (8): 354-357.

7. ClemantS, G. 1996: Sweet chery (Prunus avium L.). New York Metropolitana Flora.

8. Crane, M.B., LaWrence, W.J.C. 1956: The genetics of garden plants. MacMillan and Co., Ltd, London.

9. HeRman, J. 1971: Šumarska dendrologija. "Stanbiro". Zagreb, str. 466.

10. HIEKE, K. 1989: Praktische Dendrologie. Berlin, str. 187-219.

11. Jovanović, B. 1972: Prunus L. in M. Josifović (ed): Flora Srbije, IV: 198.

12. Jovanović, B. 2000: Dendrologija. Univerzitet u Beogradu, str. 536.

13. KleINSChMit, J., Stephan, R., WAGneR, I. 2000: Conservation of genetic resources of wild fruit trees (Prunus avium, Malus sylvestris and Pyrus pyraster). International Plant Genetic Resources Institute 2000. Www.ipgri.cgiar.org

14. KrameR, P.B., 1984: Böume. Mozaik verlag, München, str. 288.

15. KRÜSSMAN, G. 1978: Handbuch der Laubghözle. Berlin und Hamburg, Bd I-II.

16. MIKIĆ, T. 1991:Primjena metoda oplemenjivanja u podizanju intenzivnih kultura šumskog drveća u cilju povećanja proizvodnje drvne mase sa kratkim produkcionim periodom. Izvještaj za period 1989-1990 u okviru D.C.VII. Sarajevo

17. MiKIĆ, T., Ballian, D., ORLović, S. 2004: Varijabilnost plodova i semena divlje trešnje (Prunus avium L.) sa područja Bosne i Hercegovine. III Kongres genetičara Srbije. Zbornik radova. Subotica, str. 145.

18. Mıšı́́, P. 1987: Opšte oplemenjivanje voćaka. Nolit. Beograd, str. 270.

19. PANDEY, K.K.1976: Origin of genetic variability: combination of peroxidase isoenymes determine multiple allelism of the S-gene. Nature, 213: 669-672.

20. PEJKIĆ, B. 1980: Oplemenjivanje voćaka i vinove loze. Naučna knjiga. Beograd, str. 486.

21. RIEGEL, M., 2002: Encyclopedia Fruit Crops. New York.

22. RushFORTH, K. 1999: Trees. In C. Brickell (Ed.): New Encyclopedia of Plants and Flowers. London, str. 60-111.

23. RusSELL, K. 2003: EUFORGEN tehnical Guidelines for genetic consevation and use for wild cherry (Prunus avium). International Plant Genetic Resources Institute, Rome. Italy. 6 pages.

\section{Summary - Sažetak}

Wild cherry (Prunus avium L.) is one of the most important forest tree species from the productive and ecological view point both in Bosnia and Herzegovina and in several European countries. Despite its significance it is not adequately treated in Bosnia and Herzegovina. This is an attempt to examine some statistical figures about its buds, flowers and seeds in order to determine their relationships. The paper 
analyzes the relations between: the length and the width of flower buds, the length and the width of the flower and the number of flowers in a blossom, the length and the width of the seeds, and their relation to some derived ratio variables. The obtained results provide possibilities to estimate abundance of blossoming and the sizes of seeds that could be used to estimate the size of fruit. In that manner we can influence the quality of wild cherry stands established in artificial way and this can be used for selection connected with fruit quality.

The examined variables indicate wide individual intra population variability that is one of characteristics of all forest tree species in the central Dinarides. (Dinaric Alps)

The closest relationship is observed in the length and the width of the seed while other correlations are influenced with some highly non-acceptable factors.

In wild cherry populations there is a considerable participation of trees produced by spontaneous hybridization with a sort of domestic cherry. Thus, there are trees of F1, F2, F3 and other generations in the populations that influence the estimates for some variables.

The obtained results could be used as a ground for overall estimate of variability and contribute in both silviculture treatments and in the seedling stands establishment.

The obtained correlation could be used for both blossom estimation and the estimation of the seedling sizes based on the buds size in the next vegetation period.

The applied method provides good morphological structure of the population and recommends the necessary measures in the maintenance of the genetic resource in the examined populations. 